Dian Ananda Alviana and Moses Glorino Rumambo Pandin

Universitas Airlangga

Kampus B, Jalan Airlangga No. 4-6, Airlangga, Kec. Gubeng, Kota Surabaya, Jawa Timur 60115 dian.ananda.alviana-2020@,fib.unair.ac.id; moses.glorino@,fib.unair.ac.id

\title{
Book Review: \\ "THE CRITICAL LOGIC OF CLASSICAL PHILOSOPHERS; FROM THE PRE-SOCRATES TO ARISTOTLE" (LOGIKA KRITIS FILSUF KLASIK; DARI ERA PRA-SOCRATES HINGGA ARISTOTELES)
}

Aloysius Germia Dinora and Sholahuddin Al-ahmed; Yogyakarta; 2020; 978-623-244-125-5; 280 pages.

The book entitled "Logika Kritis Filsuf Klasik; Dari Era Pra-Socrates Hingga Aristoteles" (The Critical Logic of Classical Philosophers; from The Pre-Socrates to Aristotle) was written by the author to invite readers to become more familiar with the world of philosophy, especially the thoughts of philosophers who existed in Ancient Greece. That is because nowadays, philosophy is a scourge for many people. Moreover, there are still many stereotypes about philosophy, such as the notion that philosophy is not contextual to everyday life because it is attached to stereotypes that are considered problematic. Therefore, through this book, the author would like to invite readers to know the famous ancient Greek philosophers because they provide a strong foundation in philosophy. The author to readers who want and are interested in studying philosophy. The author uses light and easy to understand by ordinary people who want to study philosophy. It can be interpreted that this book is written as simply as possible by the author for readers who have just studied philosophy.

The information presented in that book is in the form of brief points regarding the core thoughts of the three great ancient Greek philosophers. The author also adds examples relating to political, economic events to problems in human relations. The author also tries to provide notes for simple philosophy. A brief description of the great philosophers after the three Greek philosophers is expected to spark readers' curiosity about philosophy again.

The book entitled "Logika Kritis Filsuf Klasik; Dari Era Pra-Socrates Hingga Aristoteles" (The Critical Logic of Classical Philosophers; from The Pre-Socrates to Aristotle) is necessary and essential to review because that book can be a starting point in learning philosophy. The biographies and thoughts of the three great ancient Greek philosophers written have become a strong foundation in philosophy. Likewise, the language that is light and easy to understand and the existence of a chapter that discusses how to do philosophy make this book suitable for readers looking to learn philosophy. Its review may give the reader sufficient consideration to use it as a precautionary measure for the study of philosophy.

The book entitled "Logika Kritis Filsuf Klasik; Dari Era Pra-Socrates Hingga Aristoteles" (The Critical Logic of Classical Philosophers; from The Pre-Socrates to Aristotle) is Aloysius Germia Dinora and Sholahuddin Al-Ahmed can fulfill the needs of the intended readers. That is because this book contains several chapters that explain philosophy associated with everyday life, how to do philosophy only, and dare to learn philosophy. So that the contents of the book correspond to the intended readership of people who had just begun to study philosophy. In addition, it also explains the biographies and thoughts of Ancient Greek philosophers whose reviews are considered to provide a strong foundation in the world of philosophy.

The new information is the writing of brief points regarding the core thoughts of the three great ancient Greek philosophers-examples relating to political, economic events, to problems in human relations. The aim is that the biographies of these philosophers can be easily understood and remembered through daily problems and activities. In addition, the first chapter of this book is entitled "Filsafat: Antara Tanda Tanya dan Jawaban" (Philosophy: Between Question Mark and Answer) which explains how to do philosophy in the era of social media, 
considering that we are currently living in a millennial era marked by the leap of information technology civilization that changes the way of life and habits. The last chapter discusses how to do philosophy can be a fun companion. The chapter helps readers awaken that philosophy is not complex and not contextual to everyday life. Conversely, philosophy can be a good listener because it teaches us logic and systematics of thinking, can expand the world of relationships, and become trendy by relying on appearance and broad insight and being an idealist.

How the book affects its readers is that the reader can study and understand philosophy simpy. It is thus hoped that readers will be able to change their outlook on philosophy, since the opportunity is now to be a scourge to many

The writings in this book invite readers to let go of the readers' fear of studying philosophy and dismiss stereotypes about the philosophy that smart people only learn. Thus, in chapter 7 under the heading "Berfilsafat Secara Sederhana," (Philosophizing Simply) it contains how loving philosophy is the same as loving life by looking at philosophy in daily activities. It is thus hoped that the reader will be able to adjust his thinking on philosophy.

The evidence contained in this book is that there are quotes that are displayed, such as "Pengetahuan yang dimiliki manusia bersifat dinamis, ..." (Human knowledge is dynamic, ...) Maksum 2006, with footnotes in each of his quotes, supporting explanations in proving its truthfulness.

The evidence contained in the book is, in a sense, conclusive. That is due to the inclusion of a footnote on each quote from the explanation of a matter. In addition, the existence of a bibliography containing the quotations from which these quotations were taken can make readers prove themselves relevant or irrelevant in the contents of the quotes. With the bibliography, it can be a reference in establishing the truth.

Starting from the second to chapter sixth, we discuss in the book the critical logic of classical philosophy from the Pre-Socrates to Aristotle in addition to the transmission of philosophical philosophy from medieval to modern times. In the second chapter discusses the Pre-Socratic era, which contains the features and history of Greek philosophy. This chapter also discusses that historians divide the three stages of Greek philosophers between making it easier to recognize the style and style of thinking found on pages 35-53, namely the Pre-Socratic era which includes the nature Thelosophy of the thinkers of Miletos (Thales, Anaximandros, Anaximenes), era Classics were marked by the emergence of philosophers with pluralist thinkers (Empedocles and Anaxogoras), and the Romawi-Yunani/Hellenistic era which was marked by the existence of two main schools of thought, namely Epicureans and Sto,ics, which adopted a philosophy called Atomism (Demokritos). The third chapter discusses a philosopher named Socrates. The chapter contains a brief biography of Socrates and also the main points of his thoughts. Systematically, Socrates' line of thinking on page 69, which can be described as the goal of human life, namely to obtain happiness (eaudaemonia), happiness can be obtained by virtue (arate), to know what and how virtue we should know with knowledge (episteme). Hence, integrity (arate) is knowledge (episteme).

Furthermore, the fourth chapter discusses a philosopher named Plato. He realized that education is the key to building a wise human being, according to his view that the moral quality of its society measures the progress of a country. The chapter also explains the Republic, which is a work that contains a dialogue between Socrates and Plato, which is found on pages 80-98. The fifth chapter discusses a philosopher named Aristotle. Aristotle became the closing of a triad of great classical Greek philosophers with the characteristic of dealing with logic. The chapter also discusses the differences between Socrates and Plato and Aristotle, written on pages 102-122. The sixth chapter examines the transmission of medieval to modern philosophy. Starting from Hellenism with the Epicurean School, the Stoic School, the Neo-Platonic School was the last phase of Greek Hellenism. As for discussing the Middle Ages, which are often referred to as the dark ages until the birth of the modern philosophy initiated by Rene Descartes. Furthermore, the Post-Modernism period until the Homo Digital Era is described on pages 136-185.

The writing in the book was by all but pieced together from an introduction to philosophy 
and the issue, then a brief description of the ancient Greek philosophers agreed with the problem. As it was era Pre-Socrates, Socrates, Plato, Aristotle, down the transmission of philosophy from medieval to modern times. The next chapter also explains how to do philosophy only and how philosophy can remain a fun companion. The author's writing style is simple, so that it is by the author's goal of introducing simple philosophy to the readers. That way, readers will easily understand philosophy because it is also linked to daily activities. In the book, it is not written that an organization dominates, so the book's writing style focuses on what the author wants to convey to readers.

In this book, there are no studies, facts, or ideas that the book's author neglected to consider for the reader. That is because it returns to the author's goal to introduce philosophy to the readers. So, the author makes the book's contents by including facts or ideas that have been completed and verified by a bibliography.

This book certainly has advantages that make it important to read. Its advantage is to explain three ancient Greek philosophers whose thinking was used as the foundation in the world of philosophy. Where the thoughts of the three philosophers are also associated with everyday life, relating it to everyday life can make it easier for readers to understand it. In addition, in the last chapter, it is explained that studying philosophy can change the mindset to be more trendy and idealistic. And also in the first chapter discusses how to do philosophy in the Millennial era or the current era of social media. Some interesting philosophers' brief biographies to be learned in the last chapter, which the writer hopes will arouse curiosity about philosophy. The author's appearance of a funny comic snippet creates an appeal for the book to be read.

The weakness of this book is that several sentences do not meet the SPOK (Subject, Predicate, Object, Adverb), which can make the reader a little confused in understanding the meaning of the sentence. Like the sentence on page 52, which reads, "Tentunya akan menjadi jelas kata Demokritos," (Would certainly become clear with Democrritos) what is confused is what the meaning of "menjadi jelas" (crystallize) is because the sentence is at the beginning of a paragraph, which means there is no explanation of the importance of the sentence before. Then there are several typo in writing words, such as the word "atu" is the word "atau" on page 51.

The reviewer's suggestion as a review of this book is to add photos of philosophers so that readers can get to know the Ancient Greek philosophers not only through their writing but also through their pictures or physical depictions. The writer can correct some sentences that are not by the grammar to be ambiguous. Then, readers are expected to read the entire contents of the book entitled "Logika Kritis Filsuf Klasik; Dari Era Pra-Socrates Hingga Aristoteles" (The Critical Logic of Classical Philosophers; from The Pre-Socrates to Aristotle), so that the purpose of the writer's writing will reach the reader.

\section{Dian Ananda Alviana \& Moses Glorino Rumambo Pandin Universitas Airlangga}

\section{REFERENCE:}

1. Dinora AG, Al-ahmed S. Logika Kritis Filsuf Klasik; Dari Era Pra-Socrates hingga Aristoteles. Yogyakarta: Sociality; 2020. 288 p.

\section{AUTHOR SHORT-BIODATA:}

Aloysius Germia Dinora is a man who was born in South Barito. The author has completed his studies at Atma Jaya Yogyakarta University with a major in Communication Studies. The author has interests in various fields of social science. The author joins the Hoshizora Foundation, an NGO engaged in education and development located in Bantul, Yogyakarta, as a Development Program.

Sholahuddin al-Ahmed is an alumnus in 2005 from UIN Walisongo Semarang by taking Aqidah Philosophy studies. The author has worked as a journalist at Republika, Jawa Post, and Suara Merdeka for ten years. Now the author is active in digital literacy and positive internet activities for the welfare of society. 